\title{
Emîr Mehmet Ali Paşa'nın Bosna-Hersek Seyahatnâmesi
}

\section{Amīr Mehmed Ali Pasha's Travelogue to Bosnia-Herzegovina}

\author{
Ömer İshakoğlu' @
}

'Sorumlu yazar/Corresponding author: Ömer İshakoğlu (Doç. Dr.), İstanbul Üniversitesi, Edebiyat Fakültesi, Doğu Dilleri ve Edebiyatları Bölümü, İstanbul, Türkiye.

E-posta: o.ishakoğlu@gmail.com ORCID: 0000-0002-3304-3897

Başvuru/Submitted: 18.03.2021 Revizyon Talebi/Revision Requested: 27.03.2021

Son Revizyon/Last Revision Received: 30.03.2021

Kabul/Accepted: 05.05 .202

Atıf/Citation: Ishakoglu, Omer, "Emîr Mehmet Ali Paşa'nın Bosna-Hersek Seyahatnâmesi", Güneydoğu Avrupa Araştırmaları Dergisi, 36 (2021), s. 119-133 https://doi.org/10.26650/gaad.899591

\section{öz}

Mısır Hidivi Tevfik Paşa'nın (1852-1892) küçük oğlu olan Emîr Mehmet Ali Paşa, uzun yıllar veliaht olmasına rağmen siyasetten uzak bir hayat yaşamış ve daha çok Nil Nehri'nde bulunan Ravza Adası'nda yaptırdığı dillere destan sarayı ve sahip olduğu Arap atlarına düşkünlüğü ile ön plana çıkmıştır. Bunun yanı sıra yaptığı seyahatlerle de gündemde kalan Emîr, bu seyahatler esnasında tuttuğu notların daha sonra yayınlanmasını sağlamıştır. Avrupa'da eğitim almış olmasından dolayı buradaki birçok ülkeyi defalarca ziyaret etmiş, ancak bununla da yetinmeyerek Kuzey ve Güney Amerika, Endonezya'da Cava Adası, Japonya, Şam ve Bosna-Hersek gibi dünyanın farklı bölgelerine seyahatlerde bulunmuştur.

Bu makalede, kendisi hakkında henüz Türkçe akademik bir çalışma yapılmamış olan Emîr Mehmet Ali Paşa'nın hayatı ve Bosna-Hersek seyahatnâmesi üzerinde durulacak ve bu eserde yer alan tarihî, coğrafî, sosyal ve kültürel bilgiler değerlendirmeye tâbi tutulacaktır.

Anahtar Kelimeler: Mehmet Ali Paşa, Bosna-Hersek, Mısır, Seyahatnâme, Hidiv

\section{ABSTRACT}

Amìr Mehmed 'Ali Pasha, the younger son of Egyptian Khedive Tawfīq Pasha (1852-1892), lived a life away from politics despite being the crown prince for many years and came to the fore with his fondness for the epic palace of languages he built on Rawḍa Island, located on the Nile river, and the Arab horses he owned. In addition, the order, which remained on the agenda with his travels, ensured that the notes he kept during these trips were published later. Because of his education in Europe, he visited many countries here many times, but not content with this, he traveled to different parts of the world, such as North and South America, Java island in Indonesia, Japan, Damascus and Bosnia-Herzegovina. 
In this article, The Life of Amir Mehmed Ali Pasha, who has not been yet conducted an academic study in Turkish, and the travelogue to Bosnia-Herzegovina will be discussed, and the historical, geographical, social, and cultural information contained in this book will be evaluated.

Keywords: Mehmed Ali Pasha, Bosnia-Herzegovina, Travel, Egypt, Khedive

\section{EXTENDED ABSTRACT}

Although Egypt was conquered by Selim I (Yavuz) at the beginning of 1517, it continued to be the favorite of France and England in the race for global supremacy. As a matter of fact, France invaded Egypt in 1798 in order to establish its dominance on the road to India.

This occupancy paved the way for the appointment of Mehmet (Muhammad) 'Alī Pasha of Qawāla as the governor of Egypt in 1805 by the Ottoman State. Mehmet 'Alī Pasha, as a leader who understood his era correctly in many aspects, exhibited a successful administration after becoming a governor. He ensured public order and adopted a centralized practice by reviving the agricultural production, trade and craft fields. Mehmet 'Alī Pasha, whose aim was to establish a great empire independent from the Ottoman Empire as the first representative of the dynasty of Turkish origin, which would continue until 1953 under the rule of Egypt, later made efforts to modernize the country with all his might. For this reason, he has been accepted as the "Founder of Modern Egypt" due to the innovations he brought to Egypt in the first half of the $19^{\text {th }}$ century and many important modern institutions he established.

Dynasty of Qawāla, which maintained its existence until 1953, held the rule of three separate consecutive states which were the Khedive (Khidiw) of Egypt from 1805 to 1914, the Sultanate of Egypt from 1914 to 1922, and the Kingdom of Egypt from 1922 to 1953. Three names stand out among the members of this dynasty within the scope of our subject. These are Egyptian Khedive Tawfīq Pasha, his eldest son 'Abbās Ḥilmī Pasha ll and his brother Amīr Mehmet (Muhammad) 'Ali Pasha.

Although Amir Mehmet 'Ali Pasha was the crown prince for many years, he lived a life away from politics, remained on the agenda mostly with his travels and he ensured that the notes he kept during these travels were published later. Due to his education in Europe, he visited many countries here many times, but not content with that, he traveled to different parts of the world such as North and South America, Java Island in Indonesia, Japan, Damascus and Bosnia-Herzegovina.

The travel book of Amirr Mehmet 'Ali Pasha to Bosnia-Herzegovina is interesting in that it reflects the characteristics of the geography in which the writer belongs and travels. As an Eastern native who grew up with European culture, Amī's knowledge and comments on Bosnia and Herzegovina, of course, reflect his own perspective. Besides, the political events he observed during his travel and heard from the notables of the region and the troubles the people experienced provide valuable information about the period. Amirr, who was treated 
as an Ottoman representative with his outfit and manner, emphasized Ottomanism in many places and expressed his wishes/desire for this geography to be under Ottoman rule again. In addition, he explicitly stated that he also collected some information for his brother 'Abbās Hilmī Pasha. As a matter of fact, he compared many issues he witnessed during his travel to similar ones in Egypt and used expressions of praise for his own country.

It is observed that Amir, who plans his trip as a civil citizen despite having an official identity, generally prefers to be out of sight and wants to get to know them more closely by mingling with the public. As a matter of fact, he has expressed this intention many times. In addition, the detailed human descriptions and comments in his travel book can be cited as evidence for this.

In this work written in a waxed language, verses, poems and proverbs related to the subject are included when necessary. An open, sincere and natural style has been used so that there is no room for any doubt that it came out of a master pencil. The author, who speaks French, German, English and Turkish, used these languages during his travel, and applied to translators in Slavic languages. It is possible to come across Turkish words in various parts of the travel book. We can list these words together with their page numbers as follows: stew (18), quilt (22), winter quarters (27), restaurant (31), paint (32), wood (33), and commander (46). These features, which reflect the author's broad culture, add both fluidity and charm to his work. With the full text of this travel book we have discussed, I believe that another travel book of Amīr, al-Rihla al-Shāmiyye (Travel Book of Damascus) should be translated into Turkish. Because both travel books contain useful information about regions that were close to us and remained under the Ottoman rule for many years. 


\section{Giriş}

Mısır; Afrika, Asya ve Avrupa kıtalarının geçiş güzergâhı üzerinde önemli bir konumda bulunmaktadır. Osmanlı İmparatorluğu, 16. yüzyılın başından itibaren Akdeniz'de Portekiz'le mücadelede bu bölgenin öneminin farkına varmış ve bu yüzden fethini hızlandırmıştır.' Mısır, Yavuz Sultan Selim tarafından 1517 senesinin başlarında fethedilmesine rağmen global üstünlük yarışında bulunan Fransa ve İngiltere'nin gözdesi olmaya devam etmiştir. Nitekim Fransa, Hindistan yolu üzerinde hâkimiyet kurabilmek amacıyla 1798'de Mısır'ı işgal etmiştir. ${ }^{2}$

Bu işgal, Kavalalı Mehmet Ali Paşa'nın Osmanlı Devleti tarafından 1805 senesinde Mısır valiliğine atanmasına zemin hazırlamıştır. Kavalalı Mehmet Ali Paşa, çağını birçok açıdan doğru kavramış bir lider olarak, vali olduktan sonra başarılı bir yönetim sergilemiştir, Kamu düzenini sağlamış, tarımsal üretim, ticaret ve zanaat alanlarını canlandırarak merkeziyetçi bir uygulamaya geçmiştir. Mısır'ın yönetiminde 1953'e kadar sürecek olan Türk asıllı hanedanın ilk temsilcisi olarak amacı Osmanlı Devleti'nden bağımsız büyük bir imparatorluk kurmak olan Kavalalı Mehmet Ali Paşa, daha sonra olanca gücüyle ülkeyi modernleştirmek için çaba sarf etmiştir. ${ }^{3}$

Mısır'ın kültürel yaşamındaki önemli değişiklikler de Kavalalı Mehmet Ali Paşa'nın izlemiş olduğu siyasetin sonucunda ortaya çıkmıştır. Onun çabalarıyla gerçekleşen birçok faaliyet, Mısır'ı bilim ve edebiyatta canlanmaya yönelterek ülkenin ilerlemesinde büyük bir paya sahip olmuştur. ${ }^{4}$ Bu yüzden 19. yüzyılın ilk yarısında Mısır'a getirdiği yenilikler ve tesis ettiği pek çok önemli modern kurumdan ötürü “Modern Mısır'ın Kurucusu” olarak kabul edilmiştir. ${ }^{5}$

1953 yılına kadar devam eden Kavalalı Hanedanlığı; 1805'ten 1914'e kadar olan zamanda Mısır Hidivliği, 1914'ten 1922'ye kadar olan zamanda Mısır Sultanlığı ve 1922'den 1953'e kadarki zamanda da Mısır Krallığı adıyla birbirinin devamı olan üç ayrı devletin yönetimini elinde tutmuştur. Bu hanedan üyeleri arasında konumuz gereği üç isim ön plana çıkmaktadır.

1 Özge Özkoç, Mısır'ın 19. Yüzyılı, Modernleşme, Merkezileşme ve Özerklik, İstanbul, Ayrıntı Yayınları, 2015, s. 31-33.

2 Süleyman Kızıltoprak, Mehmet Ali Paşa'dan II. Abbas Hilmi Paşa'ya, Mısır'da Osmanlı'nın Son Yüzyılı, İstanbul, Tarih Bilincinde Buluşanlar Derneği, 2010, s. 1.

3 Abdurrahman er-Râfi'î, Asr Muhammed Ali, 5. bs., Kahire, Dâru'l-Me‘ârif, 1989, s. 397.

4 Arzu Ertuğrul, Kavalalı Mehmet Ali Paşa Dönemi'nde Mısır'da Edebi ve Kültürel Hayat (1805-1848), yayımlanmamış yüksek lisans tezi, İstanbul Üniversitesi, 2018, s. 3.

5 Khaled Fahmy, Paşa'nın Adamları Kavalalı Mehmet Ali Paşa, Ordu ve Modern Mısır, Çev. Deniz Zarakolu, İstanbul, İstanbul Bilgi Üniversitesi Yayınları, 2010, s. 12. 
Bunlar, Mısır Hidivi Tevfik Paşab ${ }^{6}$ büyük oğlu ve yine hidivlik yapmış olan II. Abbas Hilmi Paşa ${ }^{7}$ ve kardeşi Emîr Mehmet Ali Paşa'dır.

Tevfik Paşa'nın küçük oğlu olan Emîr Mehmet Ali Paşa, uzun yıllar veliaht olmasına rağmen siyasetten uzak bir hayat yaşamış ve daha çok Nil Nehri'nde bulunan Ravza Adası'nda yaptırdığı dillere destan sarayı ve sahip olduğu Arap atlarına düşkünlüğü8 ile ön plana çıkmıştır. ${ }^{9}$ Bunun yanı sıra yaptığı seyahatlerle de gündemde kalan Emîr, bu seyahatler esnasında tuttuğu notları Mısır'a dönüşü sonrasında usta kalemlere vererek yayınlanmasını sağlamıştır. ${ }^{10}$ Avrupa'da eğitim almış olmasından dolayı buradaki birçok ülkeyi defalarca ziyaret etmiş, ancak bununla da yetinmeyerek Kuzey ve Güney Amerika, Endonezya'da Cava Adası, Japonya, Şam ve Bosna-Hersek gibi dünyanın farklı bölgelerine seyahatlerde bulunmuştur."

Bu makalede, kendisi hakkında henüz Türkçe akademik bir çalışma yapılmamış olan Emîr Mehmet Ali Paşa'nın hayatı ve Bosna-Hersek seyahatnâmesi üzerinde durulacak ve bu eserde yer alan tarihi, coğrafi, sosyal ve kültürel bilgiler değerlendirmeye tabi tutulacaktır.

6 Mısır Hidivi Tevfik Paşa (1852-1892) Mısır valisi ve ilk hidivi İsmâil Paşa'nın en büyük oğludur. Öğrenim hayatlarının bir kısmını yurt dışında geçiren kardeşlerinin aksine Mısır'da eğitim aldı ve veliaht olarak yetiştirilmeye çalışıldığından Arapçanın yanı sıra Türkçe, Farsça, Fransızca ve İngilizce öğrendi. Babasının Mısır dışına yaptığı seyahatleri sırasında ona nâiblik yaptı. Mısır'ın giderek artan dış borçlarını ödeyememesi alacaklı devletlerin Mısır maliyesini kontrol altına alma çabalarıyla sonuçlandı. Avrupalılar'a karşı yabancı düşmanlığı şekline dönüşen tepkilerin artması yüzünden özellikle İngiltere ve Fransa'nın baskıları sonucu II. Abdülhamid 26 Haziran 1879'da Hidiv İsmâil Paşa'yı azledip yerine oğlu Tevfik'i tayin etti. Tevfik Paşa'nın hidivliği sırasında karşılaştığı meseleler arasında, artmakta olan yabancı düşmanlığı, kendisinin göreve gelmesini sağlayan Avrupalı güçlerin taleplerini karşılamak ve Mısır maliyesini kontrol çabalarına karşı gelişip güçlenen yerli muhalefeti kontrol etmek gibi hususlar sayılabilir. Hakkında ayrıntılı bilgi için bkz.: Ş. Tufan Buzpınar, "Tevfik Paşa, Hidiv" Türkiye Diyanet Vakfı Islam Ansiklopedisi, 41 (2012), s. 14-15.

7 II. Abbas Hilmi Paşa (1874-1944), Mısır Hidivi Tevfik Paşa'nın büyük oğludur. İskenderiye'de doğdu. Bir süre kardeşi Mehmet Ali ile birlikte Viyana'da Theresianum okuluna devam etti. Viyana'da iken babasının 7 Ocak 1892'de ölümü üzerine Osmanlı Devleti tarafından Mısır hidivliğine tayin edildi. Abbas Hilmi'nin çok genç ve idarî işlerde tecrübesiz olması sebebiyle Osmanlı hükümeti, yıllarca Mısır fevkalâde komiserliği yapmış ve Mısır'ın idarî işlerinde büyük tecrübe kazanmış bulunan Gazi Ahmed Muhtar Paşa'yı hidive "müsteșâr-ı hâs" tayin etti. Böylece Mısır üzerinde büyük nüfuza sahip olan İngiltere'nin hidive yapacağı tesir ve telkinleri büyük ölçüde önlemeyi düşündü. Abbas Hilmi'nin dengeli bir siyaset takip etmemesi, gerek Mısır içinde gerekse dış ülkelerde muhaliflerinin çoğalmasına sebep oldu; bunun bir sonucu olarak da zaman zaman suikastlara uğradı. 1914 yazında İstanbul'a geldiği sırada da bir suikasta uğrayarak yaralandı. Kısa bir müddet sonra çıkan I. Dünya Savaşı sebebiyle bir daha Mısır'a dönemedi. 19 Aralık 1914'te İngiltere Mısır'ı himayesine aldı ve Abbas Hilmi hidivlikten azledilerek yerine ailenin en yaşısıı olan Hüseyin Kâmil getirildi. Hakkında ayrıntılı bilgi için bkz.: İlhan Şahin, "Abbas Hilmi II" Türkiye Diyanet Vakfı İslam Ansiklopedisi, 1 (1998), s. 25-26.

8 Emîr Mehmet Ali Paşa, Arap atlarının terbiyesi ile ilgili bir de kitap kaleme almıştır, bkz.: Kitâb 'an Terbiyeti'lHuyûli'l- 'Arabiyye, Matba'at Mısr, Kahire, 1935.

9 Zeki Fehmi, Safvetu'l- 'Asr fî Tarîh ve Rusûm Meşâhir Ricâl Mısr, Kahire, Mektebet Medbûlî, 1995, s. 97-98.

10 Bu iddiayı Hayreddîn ez-Ziriklî ortaya atmıştır, bkz.; el-A 'lâm: Kamûs Terâcim li-Eşheri'r-Ricâl ve'n-Nisâ min'el'Arab ve'l-Musta 'rebîn ve'l-Musteşrikîn, 15. bs., Beyrut, Dâru'l- 'Illm li'l-Melâyîn, 2002, C. VI, s. 306. Ayrıca Seyahatnâmenin 1906 yılındaki ilk baskısının kapağında, Ezher şeyhlerinden olan Muhammed Tâhâ Selîm tarafından tashih edildiği yazııııır.

11 Z. Fehmî, Safvetu'l- 'Asr, s. 96. 


\section{Emîr Mehmet Ali Paşa'nın Hayatı}

Mısır Hidivi Tevfik Paşa'nın ikinci oğlu olan Emîr Mehmet Ali Paşa, 09 Kasım 1875 yılında Kahire'de doğdu. Ağabeyi II. Abbas Hilmi Paşa ile aralarında bir yaş vardı. Annesi Emine Hanım, I. Abbas Hilmi Paşa'nın oğlu Damat İbrahim İlhâmî Paşa ile Sultan Abdülmecîd'in kızı Münire Sultan'ın kızıydı. Bu evlilikten yine Nazlı, Hatice ve Nimetullah isimli üç kız çocuğu da dünyaya gelmişti. ${ }^{12}$

İlk eğitimini 1881-1883 yılları arasında Kahire'de bulunan ‘Âbidîn semtindeki Medresetu'l-Encâl'de alan Emîr Mehmet Ali Paşa, daha sonra Ağabeyi ile birlikte askeri eğitim almak için babasının emriyle 1884 yılında önce İsviçre'nin Cenevre kentindeki Hiksos ve ardından Viyana'daki Terzyanom okullarına gönderildi. 1892 yılında babasının vefat etmesi üzerine Mısır'a çağrılan Ağabeyi ile birlikte geri dönmek zorunda kaldı ve veliaht tayin edildi. Ancak Hidivliğe atanan Ağabeyinin daha sonra Muhammed Abdulmun'im isimli bir çocuğu oldu ve bu veliahtlık düştü.

II. Abbas Hilmi Paşa, 1914 yılında İngilizler tarafından azledildi ve Emîr Mehmet Ali Paşa'dan da ülkeyi terk etmesi istendi. Bunun üzerine İsviçre'nin Montreo şehrinde ikamet etmeye başladı. Mısır Sultanı I. Fuad kendisini tekrar ülkeye davet etti ve oğlu Faruk doğuncaya kadar veliaht olarak atadı. Kanuni yaşını doldurup ülkenin başına geçinceye kadar Kral Faruk'a vasîlik te yaptı. Bu kral tarafından da veliaht olarak atanan Emîr'in bu üçüncü ve son ataması II. Fuad'ın dünyaya gelmesiyle son buldu. ${ }^{13}$

İyi bir eğitim almış olan Emîr Mehmet Ali Paşa; Fransızca, Türkçe, İngilizce ve Almancayı bilmesinin yanı sıra yüksek bir kültür seviyesine de sahipti. Buna rağmen ömrü boyunca hep ikinci adam olarak ülkesini temsil etmek zorunda kaldı. Tahta geçebileceği umuduyla daha önce de bahsi geçtiği üzere Ravza Adası'nda kendisine bir saray bile yaptırmıştı. ${ }^{14}$ Ancak 23 Temmuz 1952 yılında gerçekleşen Hür Subaylar Darbesi ile meydana gelen iktidar değişikliği neticesinde mal varlığına el konuldu ve İngiltere'den bu durum ile ilgili yardım istemesine rağmen yeterli desteği bulamadı. ${ }^{15}$ Kral olma hayallerini bir türlü gerçekleştiremeyen Emir, 17 Mart 1955 yılında İsviçre'nin Lozan kentinde hayata gözlerini yumdu ve vasiyeti üzerine Mısır'a getirilip aile kabristanına defnedildi. ${ }^{16}$

12 Velâ’uddîn Bedevî, “'̇snân ve Sittûne ‘Âm 'alâ Vefâti'l-Emîr Muhammed Ali Tevfîk”, https://www.rosaelyoussef. com/205161 (çevrimiç̧i), 13.03.2021.

13 Şîrîn el-Kürdî, "Hikayet Sûreti'l-Emîr Muhammed Ali Ellezî Nâle Lakab "Veliyyu'l-'ahd” Selâs Merrât", https://m. akhbarelyom.com/news/newdetails/3050661/1 (çevrimiçi), 14.03.2021.

14 İslam mimari sanatları örnek alınarak yapılan Menyel Sarayı, günümüzde müze olarak kullanılmaktadır. Beş bölümden oluşan bu sarayda; kabul salonu, saat kulesi, mescid, ikamet köşkü, taht salonu, özel eşyaların sergilendiği müze bölümü ve av köşkü yer almaktadır. Bu saray hakkında ayrıntıı bilgi için bkz.: Şîrîn Fevzî Abdurrahman, Kasru'l-Emîr Muhammed Ali ve Mulhakâtuhu, yayımlanmamış yüksek lisans tezi, Kahire Üniversitesi, 2009, s. 50. Emîr 'in çalışma odası ve yazı takımının sanatsal özellikleri ve değeri hakkında ayrı bir makale çalışması yapılmıştır, bkz.: Şâdiye ed-Dessûkî ve Mey Celâl Abdulbâkî, "Tâkım Mektebi'l-Emîr Muhammed Ali bi Methaf Kasri'l-Menyel", el-Mecelletu't-Tarîhiyyetu'l-Misriyye, 51 (2018), s. 267-302.

15 Enas Fares Yehia, "Prince Mohammed Ali after the July Revolution 1952 and the Journey of Searching for the Lost", Journal of the American Research Center in Egypt, Vol. 51 (2015), pp. 193-202.

16 Besme Ahmed Sıddîk, "Tercemetu'l-Emîr Muhammed Ali Tevfîk", Mecellet Ittihâdi'l-Câmi'âti'l-'Arabiyye li'sSiyaha ve'd-Diyâfe, 15/2 (2018), s. 11. 


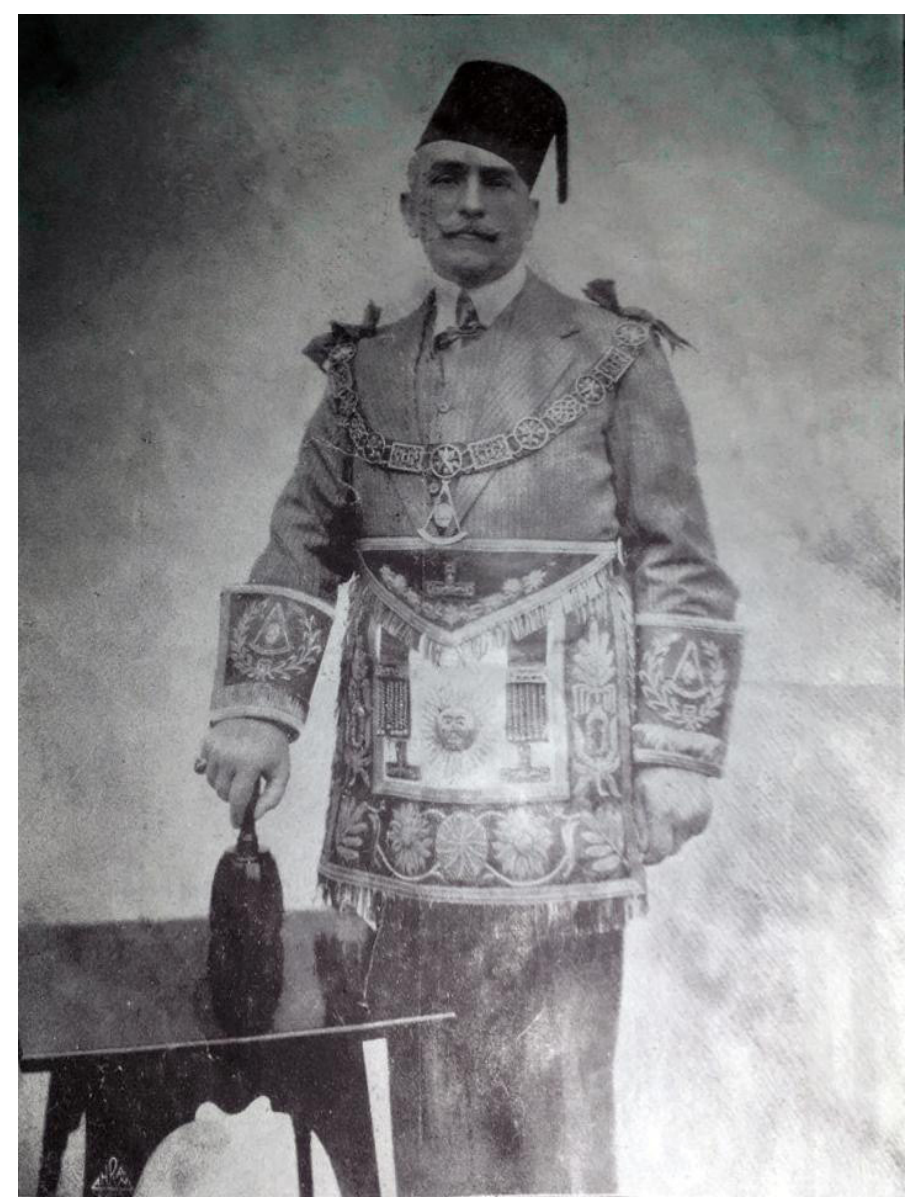

Resim 1. Emîr Mehmet Ali Paşa Mason Kıyafetiyle ${ }^{17}$

Hayatı boyunca ön planda ve göz önünde olmayı pek sevmeyen Emîr Mehmet Ali Paşa'nın bu gizemli hali ve hiç evlenmemesi, dönemin Mısır basını tarafından sürekli takip edilmesine yol açmıştır. Mısır'da bulunan Mason localarında önemli görevler üstlenmesine rağmen babası Hidiv Tevfik gibi üstad-ı azâmlığa yükselememiş ve bunu rakibi İdris Ragıp Bey'e kaptırmıştır. Buna gerekçe olarak, Emîr 'in bir görev üstlenmesi halinde sürekli toplantı ve benzer durumlar dolayısıyla bir yere bağlı kalmaktan hoşlanmaması, özgürce hareket halinde olmayı sevmesi ve seyahat etmeye olan düşkünlüğü gösterilir. ${ }^{18}$ Nitekim yaptığı sayısız seyahatler ve kaleme aldığı seyahatnâmeler buna delil olarak gösterilebilir. 


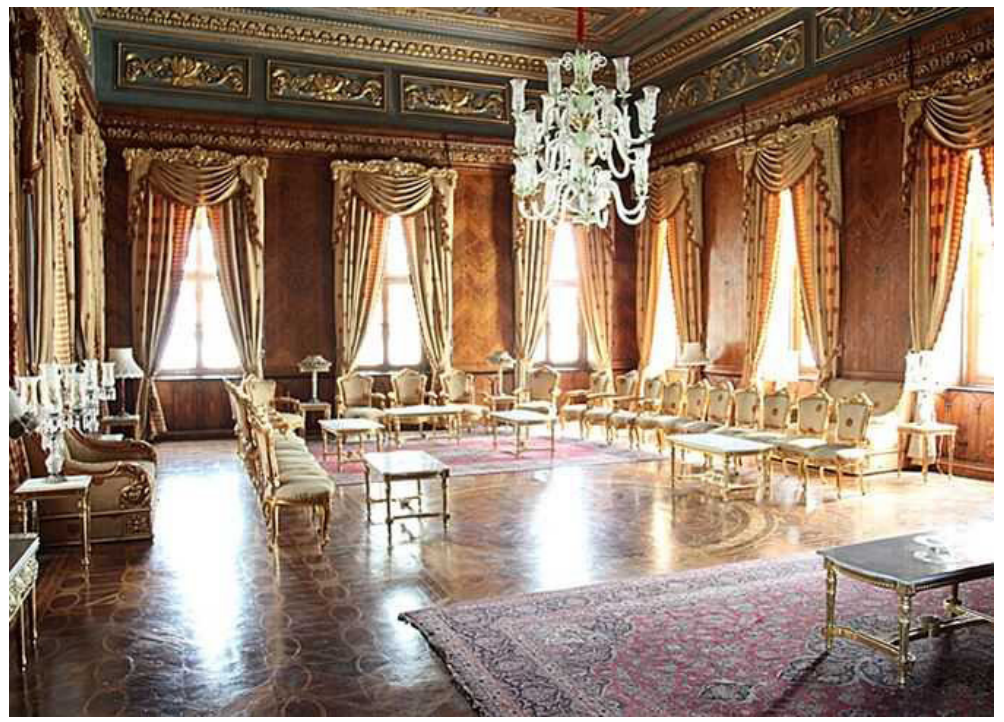

Resim 2. Emîr Mehmet Ali Paşa'nın Mısır'da Yaptırdığı Menyel Sarayı Kabul Salonu'19

\section{Emîr Mehmet Ali Paşa'nın Bosna-Hersek Seyahatnâmesi}

1900 yılının Eylül ayında gerçekleştiği için bu seyahatnâmeye Rihletu's-Sayf ilâ Bilâdi'l-Bosna ve'l-Hersek (Bosna-Hersek Ülkelerine Yaz Seyahati) ${ }^{20}$ adını veren Emîr Mehmet Ali Paşa, eserinin önsözünde bu seyahatin gerekçesini özetle şöyle ifade eder:

“Avrupa ülkelerindeki çoğu şehri defalarca ziyaret ettiğim için, hava değişimi ve dinlenmek amacıyla farklı bir güzergâh arayışı içerisindeydim. Bosna-Hersek'in gelişmekte olan bir memleket olduğunu, demiryolu ağı, otel ve lokantalar yönünden bir ziyaretçinin rahat edebileceği imkânları nispeten sağladığını duymuştum. Her ne kadar gelişmişlik yönünden Avrupa şehirlerinin ve demiryolu ağı bakımından Mısırın gerisinde olsa da bu bölgeyi ziyaret etmeye karar vermiştim. Nitekim Ingiltere'nin Mısır'daki yüksek komiseri Lord Cromer'in yardımcısı Rennell Rodd da bu seyahatim için beni teşvik etmişti" ${ }^{21}$

Avrupa'ya gerçekleştirdiği bir yolcuğun dönüşünde Paris'ten Viyana'ya gelen Emîr, burada Bosna-Hersek seyahatinin planlamasını yapar. Öncelikle Macaristan'ın başkenti Budapeşte, oradan Bosna şehirlerinden olan Banya Luka, Yayçe, Dubrovnik ve başkent Saraybosna'ya gidip buralarda bir süre kalacaktır. Daha sonra Hersek'in başkenti Mostar'a geçerek, buradan Modrica'ya ve deniz yoluyla Kataro'ya gelip Karadağ'ın başkenti Çetine'yi de ziyaret

19 Şîrîn Fevzî, Kasru'l-Emîr s. 880.

20 Yaklaşık olarak yetmiş sayfadan oluşan bu seyahatnâme, ilk olarak Mısır'da 1906 yılında basılmış ve Mu'esseset Hindâvî tarafından 2020 yılında yeniden yayımlanmıştır. Nitekim aynı yayınevi, müellifin diğer seyahatnâmelerinin de yeni baskılarını yapmıştır.

21 Mehmet Ali, Rihletu's-Sayf, s. 11-12. 
etmeyi planlamaktadır. Ancak daha sonra vakit yetersizliğinden dolayı bu seyahatini sadece Bosna şehirleri ile sınırlar. ${ }^{22}$

Bu gezisini sivil ve tamamen gayrıresmi gerçekleştiren Emîr 'in beraberinde yakın dostu Muhsin Rasim Bey'in yanı sıra üç de hizmetçi bulunmaktadır. Bunlar, Çamaşırcı Muhammed Cafer, meşhur süvari Çerkez Devlet ve Gürcü Muhammed Ağa'dır. Bu son kişiyi Karadağlı olduğu ve Slav dillerini bildiği için tercüman olarak yanlarına almışlardır. Viyana'dan trene binerek yolculuğuna başlayan Emîr, başından geçen en ufak olayı bile seyahatnâmesinde anlatmış ve sonrasında neden ayrıntıya girdiğine gerekçe olarak şunları söylemiştir:

“Muhtemelen okuyucu, çok ayrıntıya girdiğimi fark etmiştir, ama bazen küçük şeyler büyük başlıklar hakkında fikir verebilir. Mesela bir vatandaş kendi halkını temsil edebilir. Eğer bir topluluğun âdet ve davranış özelliklerini öğrenmek istersek, bunu sıradan bir bireyden bile elde edebiliriz. Çünkü onlar gösteriş ve yapmacıklıktan uzak bir halde doğal davranışlar sergilerler. Nitekim cahilin kalbi dilinde, akıllının dili kalbinde derler". ${ }^{23}$

Bu gerekçeden hareketle, Viyana'da kaldığı otelden ayrılışından itibaren olayları anlatmaya başlayan Emîr Mehmet Ali Paşa'nın bu seyahatini, aşamalı olarak başlıklandırarak şöyle özetleyebiliriz:

\section{Bosna'ya Gitmek Üzere Viyana'dan Ayrılış}

Viyana'daki otelinden ayrılarak tren istasyonuna giden Emîr, trenin birinci sınıf vagonunda beş kişilik yer bulamamaları sebebiyle hizmetçilerinin ikinci sınıf vagonda seyahat ettiğini, kondüktöre rüşvet vermesi neticesinde ancak kendisi ve arkadaşı için birinci sınıf vagonda yer bulduğunu ve bu davranışın o bölge insanı için doğal karşılanması gerektiğini aktarır. Her ne kadar kondüktör rüşveti az bulmuş olsa da yine de onlara gerekli yardımları yapmış ve Macaristan sınırına geldiklerinde, Macar kondüktöre bu yolcular ile ilgilenmesi yönünde telkinde bulunmuştur. ${ }^{24}$

Trendeki yemek vagonundan da bahseden yazar, yemeklerin lezzetli olmamasından dolayı aç kaldıklarını ve sadece ekmek yediklerini ifade eder. Ancak Jala beldesinde tren durunca, hemen inip bir lokanta bulduklarını, burada gulaş isimli yahniye benzer bir yemeği oldukça beğendiklerini ve birden fazla porsiyon yediklerini aktarır. Daha sonra hareket eden tren, gece vakti Tuna Nehri'ne doğru yaklaşır ve burada yazar hayatında ilk defa gördüğü bir olayı hayretle bizlere anlatır. Kıyıya yaklaşan büyük bir gemi, treni içerisine alarak bir kıyıdan diğerine taşıyacaktır. Burada yolcuların çoğu bu olayı hayretle izler, çünkü böylesi büyüklükte ve ağırlıktaki treni içine alacak derecede bir gemi inşa edilebilmesine bir türlü anlam veremezler. Karşıya geçen tren daha sonra yoluna devam eder ve sabah olduğunda artık Bosna sınırına yaklaşır. ${ }^{25}$

22 Mehmet Ali, Rihletu's-Sayf, s. 13.

23 Mehmet Ali, Rihletu's-Sayf, s. 16.

24 Mehmet Ali, Rihletu's-Sayf, s. 14-16.

25 Mehmet Ali, Rihletu's-Sayf, s. 16-20. 
Bosna sınırına geldiklerinde farklı bir trene binip yollarına devam edeceklerdir. Bu yüzden istasyonda birinci sınıf vagonda bilet almak için sıraya giren Emîr Mehmet Ali Paşa, bu esnada gördüğü insanların tasvirini yapar. İnsanların giyim kuşamı ve samimi davranışları sebebiyle kendisini bir Osmanlı beldesinde hissettiğini aktarır. Bu esnada, kıyafetleri ve tavırlarıyla devlet görevlisi olduğu hissini veren bir adam yanlarına yaklaşır. Çünkü Emîr'in kendisi ve beraberindekiler, başlarındaki fes ve giydikleri kıyafetlerle İstanbul'dan gelmiş kişiler gibi bir izlenim uyandırmışlardır. Bu görevli, kendilerine birçok soru yönelterek tanımaya çalışır. Emîr kendisini, yurt dışı seyahatlerde kullandığı “Mehmet Ahmet Bey” takma adıyla tanıtır. Görevlinin sorduğu en kritik sorular arasında, o dönem Hersek'in başkenti olan Mostar'a gidip gitmeme konusundaki görüşleridir. Çünkü o sıralarda Mostar'da Hristiyanlarla Müslümanlar arasında bir olay olmuştur. Buna göre Mostar'da bulunan ruhban okulunun misyonerlik çalışmaları neticesinde iki Müslüman kadın din değiştirmiş, bu durum toplumda galeyana sebep olmuş ve Avusturya İmparatoruna yapılan şikâyete rağmen bir netice alınamamıştır. Bu olayı Emîr'e nakleden görevli, Mostar'a gitmeyeceklerini öğrendiğinde memnuniyetini dile getirmiş ve bir süre muhabbet ettikten sonra yanlarından ayrılmıştır. ${ }^{26}$

\section{Saraybosna'ya Varış}

Trene binen Emîr ve beraberindekiler, uzun bir yolculuktan sonra başkent Saraybosna'ya ulaşırlar. Bu uzun yolculuk sırasında çoğu zaman uyumadan dışarıyı seyreden Emîr, gördüklerini ayrıntılı bir şekilde anlatır. Bu anlatımda doğa tasvirleri, mimari yapı, insanların kılık, kıyafet, hal ve davranışları, çiftçilikte kullanılan hayvanlar ve fiziksel özellikleri büyük bir yer kaplar. Ayrıca müşahede edilen bazı hususlar, gerek Avrupa ülkeleri ve gerekse Mısır ile karşılaştırma yapılarak aktarılır. Yeri geldiğinde bazı yorumlar da yapan Emîr, bu güzel beldelerin Osmanlı idaresinden çıkmış olmasına hayıflanarak üzülür. ${ }^{27}$

Tren istasyonundan otele doğru yol alan Emîr, yol boyunca Saraybosna caddelerinin geniş, düzenli ve temiz olmasından duyduğu hayranlığı dile getirir. Ayrıca caddenin ortasından elektrikli tramvay da geçmektedir. Burada kendilerine yardımcı olup, rehberlik yapması için bir zamanlar Arnavutluk'un Avlonya şehrinde konsolosluk yapmış olan arkadaşını arayan Emîr, arkadaşının Saraybosna'ya dört saatlik bir mesafede olduğunu, ancak kardeşi Petroviç'in bu hizmeti sunabileceğini öğrenir. Daha sonra bu kişiyle tanışarak, şehirde gezilip görülmesi gereken yerler hakkında planlama yaparlar. ${ }^{28}$

\section{Saraybosna'da Gezilecek Yerler}

Saraybosna'daki ilk durakları Gazi Hüsrev Bey Camii'dir. Burada hem camiyi hem de Gazi Hüsrev Bey'in türbesini ziyaret ederler. Ardından İslâmi ilimlerin okutulduğu medreseye geçen Emîr, bu yapının dışarıdan bakımsız, içeriden ise nispeten daha bakımlı olduğunu naklederek, girdiği sınıflardan birinde tahtada yazan Arapça ibareleri görünce mutlu olduğunu ifade

26 Mehmet Ali, Rihletu's-Sayf, s. 20-22.

27 Mehmet Ali, Rihletu's-Sayf, s. 22-26.

28 Mehmet Ali, Rihletu's-Sayf, s. 27-31. 
eder. Buradan da çıkıp Sırp Kilisesi'ni ziyaret ederler. Sırada Saraybosna'nın çarşıları vardır. Illk gittikleri çarşının yeterince büyük olmadığını ifade eden yazar, burada satılan ürünlerden de bahseder. Burada ilgisini çeken diğer bir husus da dükkânların üzerinde Türkçe "Padişahımız Çok Yaşa" yazılı olmasıdır. Ardından eski Yunan kilisesinden dönme bir çarşıya uğrarlar. Bu çarşının esnafının çoğu Yahudi'dir ve Avusturya'dan getirdikleri düşük fiyatlı kumaş ve benzeri ürünleri köylülere satmaktadırlar. Daha sonra çarşıdan ayrılan Emîr ve beraberindekiler, Heyşa bölgesinde bulunan kaplıcalara giderler. Bu kaplıcalar, dönemin hükümeti tarafından karşılanan bütçe ile yapılmıştır. Ancak ülkede gerçekleştirilen birçok imar projesine rağmen halk baskı gördüğünü ifade ederek hükümetten memnuniyetsizliğini dile getirmektedir. Müslümanlar, Türk hâkimiyeti; Sırplar ise kendi hükümetlerinin idaresi altında yaşamayı temenni etmektedirler. Bu hoşnutsuzluğun diğer bir sebebi de hükümetin desteklediği kiliselerin halk üzerinde dini ve mezhebi baskı oluşturmasıdır. Buradan da ayrılan grup, ilk günkü gezilerini tamamlamış bir halde otele geri dönüş yapar.

Ertesi gün ise, aynı grup bu sefer Saraybosna'da bulunan yerel bir müzeyi ziyaret ederek gezisine başlar. Burada mumdan yapılmış heykeller üzerinde gösterilen yöresel kıyafetlerin yanı sıra cam vitrinler içerisinde fermanlar, eski para ve sikkeler sergilenmektedir. Bu müze ziyaretinin ardından yöresel halıların dokunduğu bir atölye ile tütün fabrikası ziyaretleri yer alır. Özellikle tütün fabrikasının devasa oluşu ile üretilen kaliteli sigaraların Avrupa ülkelerine ve özellikle Almanya'ya ihraç edildiği yönündeki bilgiler, ziyaretçilerin ilgisini çekmiştir. Günün sonunda tekrar otele dönen grup, bir sonraki gün Yayçe'ye gitmek üzere hareket edecektir. Bu arada aynı gün Emîr 'in Avusturya'daki okuldan arkadaşı Bakır Bey, Tuzla şehrinden gelip kendisini ziyaret eder. Yaşadığı bölgedeki Müslümanların liderliğini yürüten bu şahıs, yaşadıkları sıkıntılar ile yaşanan siyasi gelişmeler hakkında Emîr'e bilgiler verir ve otelde bir gece kalarak, ertesi gün onları Yayçe'ye uğurlar. ${ }^{29}$

\section{Yayçe Şehrine Hareket}

Saraybosna gezisini tamamlayan Emîr ve beraberindekiler, Yayçe'ye gitmek üzere trene binerler. Tren Dubrovnik şehrinden geçer, ancak burada kalacak zamanları yoktur. Emîr, yolculuk boyunca gördüğü doğa ve insan manzaralarını yine bize aktarır. Yayçe'ye ulaştıklarında önce kalacakları otele giden grup, ardından şehri gezmeye başlar. İlk durakları Yayçe Kalesi'dir. Burada bir rehber eşliğinde kaleyi dolaşırlar, ancak bu rehber Hristiyan olduğu için sürekli Osmanlıyı kötülemektedir. Ayrıca kalenin etrafında yaşayan Müslüman halkın giyim, kuşam ve âdetleriyle ilgili de alaycı bir tavır sergiler. Bunun üzerine kendini tutamayan Emîr, bu rehbere hak ettiği bir ders vererek kalenin bölümlerini anlatırken verdiği yanlış ve taraflı bilgileri düzeltir. Bunun yanı sıra Müslümanlarla ilgili sarf ettiği sözlerin haddi aştığını yüzüne vurur. Bu ziyaretinden memnun kalmayan Emîr ve beraberindekiler, methini çok duydukları ve Yayçe'ye birkaç kilometre uzaklıkta bulunan Jezero bölgesine ve Pliva vadisine doğru yol

29 Mehmet Ali, Rihletu's-Sayf, s. 31-44. 
alırlar. Buradaki Pliva nehri, doğal göller ve eşsiz doğa manzaraları görenleri büyülemektedir. Böyle bir manzara ile karşılacağını tahmin edemeyen Emîr, gördüklerini kelimelere sığdıramaz ve bu seyahat boyunca çektiği yorgunluk ve sıkıntıların buna değdiğini itiraf eder. Daha sonra dönüp Yayçe merkezinde ve çarşılarında dolaşan Emîr, Müslüman halkın büyük teveccühü ve ilgisi ile karşılaşır. Özellikle toplumun önde gelenlerinden birisi, gelip kendileri ile tanışır ve onları evine davet eder. Zaman yetersizliğinden dolayı bu daveti kabul edemeyen Emîr, bir süre bu kişi ile görüşür ve Müslümanların bu coğrafyada çektikleri sıkıntıları dinler. Edindiği bilgilerden hareketle bu kişiye izlemeleri gereken siyaset hakkında nasihatlerde bulunur ve kendisi ile vedalaşarak otele geri döner. ${ }^{30}$

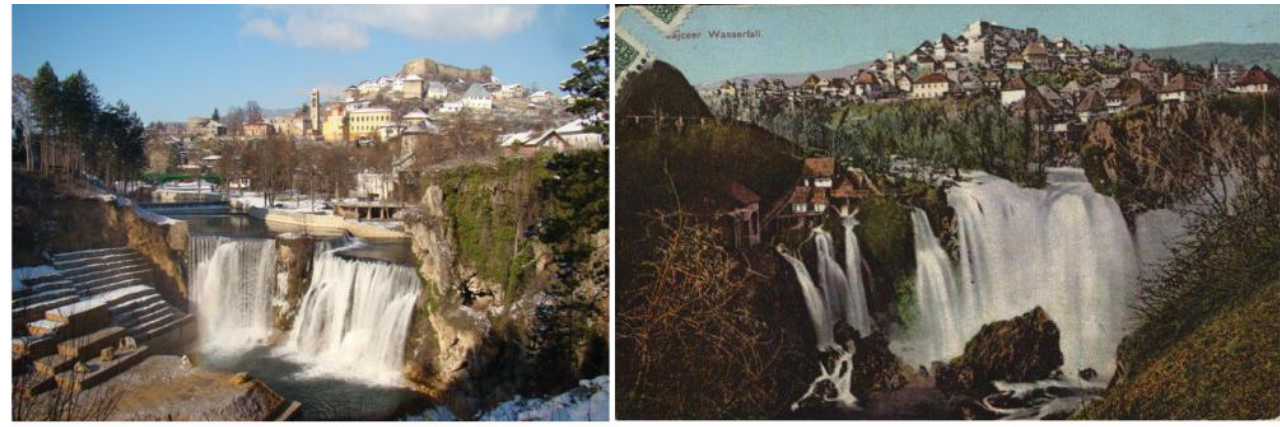

Resim 3. Geçmişte ve Günümüzde Pliva Vadisi ve Şelaleri ${ }^{31}$

Seyahatnâmenin bu bölümünde, yolculuk yapmanın ve yeni yerler görmenin faydalarına değinen yazar, özellikle Bosna'ya gelmiş olmanın ne kadar isabetli bir karar olduğunu ve birçok konuda yeni bilgiler edindiğini dile getirir. ${ }^{32}$

\section{Banya Luka'ya Hareket}

Yayçe'den ayrılan Emîr ve beraberindekiler, kiraladıkları at arabası ile Banya Luka'ya doğru hareket ederler. Uzun süren bu yolculuk boyunca, gördüğü en küçük ayrıntıyı bile not eden yazar, daha önce de olduğu gibi hem doğa hem de insan manzaralarını tasvir ederek yorumlarda bulunur. Banya Luka'ya vardıktan sonra şehirde kısa gezilerde bulunur, diğer taraftan da memleketine dönüş hazırlıklarına başlar. Bu esnada kaldıkları otele gelen bir polis, kendilerini emniyet müdürünün görmek istediği haberini verir. Bu davete şaşıran Emîr, kendilerini kimin ihbar ettiğini düşünmeye çalışır ve sonunda otelde çalışan kat görevlisi kadından şüphelenir. Çünkü mum ışığı yetersiz olduğu için kendisinden gaz lambası getirmesini talep etmiş ve bu esnada kadın kendisinin notlar aldığını görmüştür. Büyük ihtimalle casusluk iddiası ile görevlilere ihbar edilmesi üzerine emniyetten böyle bir talepte bulunulmuştur. Bu davete icabet eden Emîr, arakadaşı Muhsin Rasim Bey ile birlikte emniyetin yolunu tutar.

30 Mehmet Ali, Rihletu's-Sayf, s. 44-54.

31 Emir Temimović ve Dragan Glavaš, "The Pliva Lakes - Sustainable Management and Tourism Valorization” Acta Geographica Bosniae et Herzegovinae, 7 (2017), s. 45.

32 Mehmet Ali, Rihletu's-Sayf, s. 54-55. 
Kendilerini sert bir yüz ifadesi ile karşılayan emniyet müdürü, öncelikle kendilerini tanıtmalarını, ardından da Bosna'ya geliş sebeplerini açıklamalarını ister. Burada gerçek kimliğini açıklayan Emîr, müdürün ikna olmaması üzerine Avusturya'daki elçilikten aldığı izin kararını gösterir ve kendisine gösterilen muameleden duyduğu hoşnutsuzluğu dile getirir, sonunda da serbest bırakılarak otele geri döner. ${ }^{33}$

\section{Seyahatin Sonu ve Mısır’a Geri Dönüş}

Ertesi gün dönüş yolculuğuna başlayan Emîr ve beraberindekiler, trenle önce Zagrep'e oradan da İtalya'nın sahil şehri Trieste'ye varır ve buradan da deniz yoluyla Mısır'a geri döner. Seyahatnâmesini bir sonuç bölümüyle tamamlayan Emîr, burada bu yolculuğu kendisine nasip eden Allahu Teâla'ya hamdeder. Gezdiği yerlerdeki Müslümanların durumunun çok kötü olmadığııı, kendilerini güçlü ve kararlı gördüğünü ve Allah'ın inayetiyle tekrar bulundukları bölgelere hâkim olabilecekleri ümidini taşıdığını dile getirir. Son olarak Sultan II. Abdülhamid ve Ağabeyi Hidiv II. Abbas Hilmi Paşa için dua ve niyazlarda bulunarak sözlerine son verir. ${ }^{34}$

\section{Sonuç ve Değerlendirme}

Seyahatnâmeler, edebi türde eserler olmalarının yanı sıra içerdikleri siyasî, coğrafî, tarihî, sosyal ve iktisadi bilgiler ile de yazıldıkları dönemlere ışık tutarlar. Emîr Mehmet Ali Paşa'nın bu seyahatnâmesi ise; hem yazarın mensup olduğu hem de seyahat ettiği coğrafyanın özelliklerini yansıtması açısından ilgi çekicidir. Avrupa kültürü ile yetişmiş bir Doğulu olarak Emîr'in Bosna-Hersek'e dair verdiği bilgiler ve yaptığı yorumlar, tabii ki kendi bakış açısını yansıtmaktadır. Ancak seyahati sırasında müşahede ettiği ve bizzat halkın ileri gelenlerinden duyduğu siyasi olaylar ile halkın çektiği sıkıntılar dönem ile ilgili değerli bilgiler vermektedir. Giyim, kuşamı ve sergilediği duruşla Osmanlı temsilcisi gibi muamele gören Emîr, birçok yerde Osmanlıclık vurgusu yapmış ve bu coğrafyanın tekrar Osmanlı hâkimiyetine girmesi yönündeki temennilerini dile getirmiştir. Diğer taraftan Ağabeyi Hidiv II. Abbas Hilmi Paşa için de bazı bilgiler topladığını açıkça söylemiştir. Nitekim seyahati esnasında gördüğü birçok hususu Mısır'daki benzerleriyle karşılaştırmış ve kendi memleketini övücü sözler kullanmıştır.

Resmi bir hüviyete sahip olmasına rağmen sivil bir vatandaş olarak gezisini planlayan Emîr'in, genelde gözden uzak olmayı tercih ettiği ve halkın arasına karışarak onları daha yakından tanıma isteği duyduğu görülmektedir. Nitekim bu niyetini defalarca dile getirmiştir. Ayrıca seyahatnâmesinde verdiği ayrıntılı insan tasvirleri ve yorumları buna delil olarak gösterilebilir.

Ağdalı bir dille yazılan bu eserde, yeri geldiğinde konu ile ilgili ayet, şiir ve atasözlerine yer verilmiştir. Usta bir kalemden çıktığına dair şüpheye mahal vermeyecek derecede açık, samimi ve doğal bir üslup kullanılmıştır. Fransızca, Almanca, İngilizce ve Türkçe bilen yazar, seyahati sırasında bu dilleri kullanmış, Slav dillerinde ise tercümanlara başvurmuştur. Seyahatnâmenin çeşitli yerlerinde Türkçe kelimelere rastlamak mümkündür. Bu kelimeleri sayfa

33 Mehmet Ali, Rihletu's-Sayf, s. 55-64.

34 Mehmet Ali, Rihletu's-Sayf, s. 64-66. 
numaraları ile birlikte şöyle sıralayabiliriz: yahni (18), yorgan (22), kışlak (27), lokanta (31), boya (32), tahta (33) ve kumandan (46). Yazarın geniş kültürünü yansıtan bu hususiyetler, esere hem akıcılık hem de çekicilik katmaktadır. Ele aldığımız bu seyahatnâmenin tam metni ile Emîr'in bir diğer seyahatnâmesi olan er-Rihletu'ş-Şâmiyye'nin (Şam Seyahatnâmesi) Türkçeye kazandırılması gerektiği kanaatini taşımaktayım. Çünkü her iki seyahatnâme de bize yakın ve Osmanlı hâkimiyeti altında uzun yıllar kalmış bölgeler hakkında faydalı bilgiler içermektedir.

Peer-review: Externally peer-reviewed.

Conflict of Interest: The author has no conflict of interest to declare.

Grant Support: The author declared that this study has received no financial support.

Hakem Değerlendirmesi: Dış bağımsız.

Çıkar Çatışması: Yazar çıkar çatışması bildirmemiştir.

Finansal Destek: Yazar bu çalışma için finansal destek almadığını beyan etmiştir.

\section{Bibliyografya}

Abdurrahman, Şîrîn Fevzî, Kasru'l-Emîr Muhammed Ali ve Mulhakâtuhu, yayımlanmamış yüksek lisans tezi, Kahire Üniversitesi, 2009.

Bedevî, Velâ'uddîn, “ísnân ve Sittûne ‘Âm 'alâ Vefâti'l-Emîr Muhammed Ali Tevfîk”, https://www. rosaelyoussef.com/205161 (çevrimiçi), 13.03.2021.

Buzpınar, Ş. Tufan, “Tevfik Paşa, Hidiv” Türkiye Diyanet Vakfı İslam Ansiklopedisi, 41 (2012), s. 14-15.

Dessûkî, Şâdiye ve Abdulbâkî, Mey Celâl, “Tâkım Mektebi'l-Emîr Muhammed Ali bi Methaf Kasri'lMenyel”, el-Mecelletu't-Tarîhiyyetu'l-Mısriyye, 51 (2018), s. 267-302.

Emîr Mehmet Ali Paşa, Kitâb 'an Terbiyeti'l-Huyûli'l- 'Arabiyye, Matba'at Mısr, Kahire, 1935.

Emîr Mehmet Ali Paşa, Rihletu's-Sayf ilâ Bilâdi'l-Bosna ve'l-Hersek, Mu'esseset Hindâvî, Birleşik Krallık, 2020.

Ertuğrul, Arzu, Kavalalı Mehmet Ali Paşa Dönemi'nde Mısır'da Edebi ve Kültürel Hayat (1805-1848), yayımlanmamış yüksek lisans tezi, İstanbul Üniversitesi, 2018.

Fehmi, Zeki, Safvetu'l- 'Asr fî Tarîh ve Rusûm Meşâhir Ricâl Mısr, Kahire, Mektebet Medbûlî, 1995.

Fahmy, Khaled, Paşa'nın Adamları Kavalalı Mehmet Ali Paşa, Ordu ve Modern Mısır, Çev. Deniz Zarakolu, İstanbul, İstanbul Bilgi Üniversitesi Yayınları, 2010.

Kızıltoprak, Süleyman, Mehmet Ali Paşa'dan II. Abbas Hilmi Paşa'ya, Mısır'da Osmanlı'nın Son Yüzyılı, İstanbul, Tarih Bilincinde Buluşanlar Derneği, 2010.

Kürdî, Şîrîn, “Hikayet Sûreti'l-Emîr Muhammed Ali Ellezî Nâle Lakab "Veliyyu'l- 'ahd” Selâs Merrât", https://m.akhbarelyom.com/news/newdetails/3050661/1 (çevrimiçi), 14.03.2021.

Özkoç, Özge, Mısır'ın 19. Yüzyılı, Modernleşme, Merkezileşme ve Özerklik, İstanbul, Ayrıntı Yayınları, 2015. Râfiî, Abdurrahman, Asr Muhammed Ali, 5. bs., Kahire, Dâru'l-Me‘ârîf, 1989.

Sıddîk, Besme Ahmed, “Tercemetu'l-Emîr Muhammed Ali Tevfîk”, Mecellet Ittihâdi'l-Câmi 'âti'l- 'Arabiyye li's-Siyaha ve'd-Diyâfe, 15/2 (2018), s. 11-18. 
Şahin, İlhan, “Abbas Hilmi II”, Türkiye Diyanet Vakfı İslam Ansiklopedisi, 1 (1998), s. 25-26.

Temimović, Emir, ve Glavaš, Dragan, "The Pliva Lakes - Sustainable Management and Tourism Valorization" Acta Geographica Bosniae et Herzegovinae, 7 (2017), s. 39-53.

Yehia, Enas Fares, "Prince Mohammed Ali after the July Revolution 1952 and the Journey of Searching for the Lost", Journal of the American Research Center in Egypt, Vol. 51 (2015), pp. 193-202.

Ziriklî, Hayreddîn, el-A 'lâm: Kamûs Terâcim li-Eşheri'r-Ricâl ve'n-Nisâ min'el- 'Arab ve'l-Musta 'rebîn ve'l-Musteşrikîn, 15. bs., Beyrut, Dâru'l-‘'llm li’l-Melâyîn, 2002, C. VI, s. 306. 
